Н. М. Малюга

\title{
СТВОРЕННЯ КОМІЧНОГО ЕФЕКТУ ЗАСОБАМИ СЛОВОТВОРЕННЯ (ПРО МОВНЕ ЧУТТЯ ОСТАПА ВИШНІ)
}

Малюга Н. М. Створення комічного ефекту засобами словотворення (про мовне чуття Остапа Вишні).

У статті йдеться про особливості використання словесних засобів комічного в мові творів Остапа Вишні. Описано стилістично зумовлені порушення словотвірних норм, продукування «словотворчих пародій» за зразком книжної мови. Стверджується, що всі похідні взаємопов'язані й за формою, і за змістом, їхне функціонування в мовному контексті підпорядковане авторському задуму. Обгрунтовано доречність представлених письменником псевдоетимологічних тлумачень та псевдоісторичних коментарів як спосіб висміювання невігластва i графоманії в науці.

Ключові слова: словотвірні засоби створення комічного, словотвірна норма, спосіб словотворення, хибна мотивація, псевдоетимологічні тлумачення.

๑) Н. М. Малюга, 2016. 
Малюга Н. Н. Создание комического эффекта средствами словообразования (о языковом чутье Остапа Вишни).

В статье говорится об особенностях использования словесных средств комического в языке произведений Остапа Вишни. Описаны стилистически обусловленные нарушения словообразовательных норм, продуцирование «словообразовательных пародий» по образцу книжного языка. Утверждается, что все производные взаимосвязаны и по форме, и по содержанию, их функционирование в языковом контексте определяется авторским замыслом. Обоснована уместность предложенных писателем псевдоэтимологических толкований и псевдоисторических комментариев как способ обличения невежества и графомании в науке.

Ключевые слова: словообразовательные средства создания комического, норма словообразования, способ словообразования, ошибочная мотивация.

Maliuga N. M. Creating comic effect by means of word formation (linguistic sense of ostap vyshnya).

The article deals with the comic verbal means in the works of Ostap Vyshnya. This paper confirms conscious word standards violation and describes the creation of humorous, satirical, ironic effects due to the usage of stylistic structural word means.

Ostap Vyshnya produces "comic" words (similar to existing words) indicating the action (derived from occupation, profession, place of the performance etc.), the subject concepts, marking nominations by means of adding affixes to initial words that do not correspond to the norms of Ukrainian literary language.

This research shows that the humorist tends to certain condensation in the semantics of his poetic language and using the bookish models, he actively creates difficult for pronounciation units, so called his own style of "derivation parody". Thanks to excessively complicated structure such language units consisting from several stems and affixes dim their primary lexical meaning and become pun words.

One of the main means to produce stylistically marked units in the poetic language of Ostap Vyshnya is lexical and semantic word forming method, which is actively determined in the category of proper names. All the derivatives are interrelated in their form, content and the performance in the language context according to the author's intention.

Ostap Vyshnya is aware of the idea that comic effects reduce the distance in the interpersonal communication, uncover the hidden irony and help in percepting jokes. Above mentioned writer, ridiculing ignorance in sciences, supplies pseudoetymological interpretation with pseudocommentary. The conscious use of false motivations, interpretation and pseudoetymology is a defining feature of Ostap Vyshnya's poetic style.

Key words: word formation means creating comic effects, derivation standard, word formation method, false motivation, pseudoetymological interpretation.

Дослідження словесних засобів комічного - важливий напрямок сучасної філологічної науки. Це насамперед вивчення мовних явищ, які спричиняють сміх, і особливостей їх використання у творчості того чи того письменника. Роль словотвірних стилістичних засобів для створення комічного (гумористичного, сатиричного, іронічного) 
ефекту вивчали В. Виноградова, О. Калита, лексичні засоби створення комічного - О. Кузьмич, Т. Пересунько, Я. Януш та ін. [4].

Дослідники в царині лінгвостилістики лише побіжно торкаються мовної майстерності Остапа Вишні у створенні комічного. Поділяємо думку Б. Пришви, одного 3 перших дослідників мови гумориста: «Глибока обізнаність 3 різними стилями мови, 3 iii лексичними шарами і різновидами давала можливість письменникові майстерно використовувати скарбницю українського народного гумору, створювати надзвичайно ефективні засоби комічного» [6, с. 114]. Остап Вишня мав особливе мовне чуття, він розширив комічні можливості рідного слова в метафоричному, метонімічному, тавтологічному вживанні; розкрив ряд ефективних різновидів гумористичного використання слів із широким і вузьким значенням, iз спотвореним звуковим комплексом; створив арсенал контрастних неологізмів; увів нові варіанти комічної евфемізації [6, с. 20].

У праці «Виникнення і розвиток літературних мов» академік Л. Булаховський зазначає: «Хай вигадані відповідним митцем нові слова залишаються назавжди тільки його словами, хай вони не надходять до активного фонду загальної мови, але там, де їх ужито, вони живуть своїм повним художньо-естетичним життям. На своєму місці вони $є$ збагаченням мови як засобу служити виявом певної дійової образності та емоційності і, подобаючись хоча б певному колу читачів, тим самим виправдовують своє народження і своє існування» $[1$, c. 136]. Цілком погоджуємося з Ж. Колоїз, яка пише: «Продукти вербальної комунікації $\epsilon$ результатами чи то узуальних, чи то оказіональних дериваційних процесів, реалізують конкретні прагматичні цілі та відповідний функціонально-стилістичний потенціал» [5, с. 223].

Стилістичні можливості словотвору виявляються при зіставленні слів, які мають однаковий корінь і значення, але різне словотворче оформлення. Одним із найбільш стилістично виразних словотворчих засобів є суфікси.

Як відомо, слова із суфіксами позитивної і негативної оцінки мають яскраво виражене емоційно-експресивне забарвлення. Приєднуючись до основи слова, ці суфікси вносять додаткові відтінки здрібнілості, пестливості, ласкавості, ніжності, зневаги, згрубілості тощо. У мові Остапа Вишні емоційно-оцінні суфікси із значенням 
здрібнілості-пестливості вживаються на позначення лише зменшеності рідко, вони досить активно слугують засобом вираження іронії. У такому разі простежуємо семантичну несумісність імені та його атрибута. Наприклад: Кримські гори - так само не низенькі, не маленькі й не коротенькі... (3, с. 75).

У разі, коли демінутивність поєднується із значенням позитивної оцінки, ласкавості, мова накладає семантичні обмеження на твірні основи. У мові творів Остапа Вишні простежуємо свідоме порушення словотвірної норми: Ось і Нікітський сад... Знаменитий і славнозвісний ботанічний садок, мабуть, чи не на цүілу Європу... (3, с. 89); То птичка пурхнула через озеро; може, очеретянка, може, бугайчик, а може, по рясці пробігла чорнявенька дика курочка (3, с. 161); Хай иарствує покійничок (3, с. 4). Так, лексичне сполучення ботанічний сад означає науковий i культурно-освітній заклад, у якому вивчають і демонструють різні рослини [2, с. 1094], а, як відомо, компоненти стійкого словосполучення не можуть зазнавати модифікаційних змін. Бугай 2. Нічний болотяний птах із родини чапель [2, с. 65]. Покійник. Померла людина; небіжчик // Уживається для вказівки, що той, про кого говорять, уже не живе [2, с. 840].

Остап Вишня конструює оказіональні демінутивні іменники середнього роду із суфіксом -ен-: І гарби, і вози, і возенята ... (3, с. 22); Придбали ви чудесне, приміром, пойнтереня (3, с. 123). Значення недорослості в наведених ілюстраціях знівельовано.

Збільшувально-згрубілі суфікси відіграють важливу роль як експресивно-характеристичні засоби. У художній літературі їхня функція - підкреслення сили, міцності, великого розміру. Похідні лексеми 3 цими суфіксами вживаються і для вираження зневаги, презирства, грубої характеристики. Суфікси -ак-, -аг-, -уганпоєднують аугментативне значення 3 фамільярно-зневажливим відтінком: Як я вже назнав, де вже сідає такий табуняка, так я ж $і$ заряд відповідний повинен мати (3, с. 138); Вчив мене хороший учитель Іван Максимович, доброї душі дідуган, білий-білий, як білі бувають у нас перед зеленими святами хати (3, с.6). У досліджуваних творах часом натрапляємо на похідні зі збільшувально-згрубілими суфіксами, які виражають фамільярну прихильність. Як свідчить ілюстративний матеріал, у цих типах 
можлива нейтралізація аугментативного значення i розвиток позитивної оцінки: Я вже був чималим чолов'ягою (3, с. 42).

Похідні комічні назви предметних понять містять суфікси, які за нормами української літературної мови не приєднуються до цих твірних: Чорний красунь кипарис (3, с. 97); Він ворожсій! (3, с. 98); Співали вони так, щзо їхні сусіди, атлантидяни оті самі, аж вікна, було, зачиняють... (3, с. 44); Починається виховання мисливського собаки, а від виховання залежить все: $i$ добутливість вашого полювання, $i$ вся краса й насолода від полювання з мисливською собакою високих кровей $(3$, с. 123$)$.

Чисельними $є$ ненормативні новоутворення iз значеннями ознаки (прикметники та прислівники): Якби вам щзе штук із четверо гірських, - ну хоч козинячих ніг, та якби ззаду за вами бігло штук із троє хортів та цүілкий мисливецьь, - ви б отих «дванадцяять верстов» узяли за півгодини... (3, с. 88); Коли в качачому полюванні більшу вагу мали помідори й огірки, то тут їх заміняють сало й ковбаса (3, с. 117); Спочатку було тяжкувато, бо папір попервах був поганкуватий $і$ чорнило не дуже добре, та й олівці часто ламались, а потім, як «Книгоспілка» взялась постачати добре канциприладдя стало легше (3, с. 10); Бандит був молодиий, піратіший (бистріший), але не такий досвідчений, як Докучай, голос у нього був із заливом, тонкий, заливчастий (3, с. 184).

Остап Вишня продукує «комічні» слова (аналогічно до наявних слів), що позначають дію (за родом діяльності, професією, місцем, де відбувається дія): Дика качка любить убиватись тихими-тихими вечорами ... (3, с. 106); Летіла, побачила, щуо націляюсь, виходу не було, взяла й... зарізалась... (3, с. 108); Населення хліборобствує, виноградарствує, садівникує, скотарствує і курортствує (3, с. 70).

Стилістично виразнішими роблять слова й префікси. Особливої експресії набувають слова 3 префіксом по-, що має дистрибутивне значення: Бо однаково, коли приїдете додому, члени вашого посемейства спитають вас: - Дорогі, мабуть, тепер качки? (3, с. 108); - Досить, досить! - поспішає посемейство... (3, с. 117); - А де ж рушниия? - питається посемейство (3, с. 120); Напружена тиша. Тільки все посемейство суворо якось дихає (3, с. 125).

За допомогою префікса недо- виражається відтінок неповноти виконання дії: Як я на неї видерся, вбийте мене, й досі недопойму... 
(3, с 155). Префікс про- в дієсловах означає «випустити, пропустити що-небудь, здійснюючи дію, названу мотивуючим словом»: Одна була лисичача капелюха, та й ту прополював (3, с. 113). Префікс підуживаний із значенням «дію, названу мотивуючим словом, здійснити 3 незначною інтенсивністю», наприклад: A тепер би ще писалося, та, знаєте, треба підмемуарити життя пройдене (3, с. 10), де підмемуарити означає підправити, підкоректувати. У мові Остапа Вишні такі оказіональні деривати є непоодинокими.

У наступних ілюстраціях простежуємо виразну стилістичну функцію ужитих препозитивних морфем: ...крик бугая на болоті бринить в їхніх вухах, як козловське распроп'янісімо ля в сериі тихомрійної блондинки ... (3, с. 115); А ви, маститий, сопричислений до старої дегенерації, коли до вас прийде хто-небудь з молодої дегенерації письменників, говоритимете: - Писати, товаришу, складна итука! (3, с. 10) Так, префікса рас- літературна українська мова не знає; зважаючи на семантику п'янісімо - дуже тихо, ще тихіше, ніж піано (про силу звуку при виконанні музичного твору), - черезступеневий (не існує слова $з$ префіксом про-) оказіональний дериват слід кваліфікувати як «майже нечутно». У другому прикладі префікс де-, що означає 1) віддалення, виділення, скасування, припинення, усунення чогонебудь; 2) рух донизу, зниження, змінює значення слова генерація (покоління) на дегенерація (виродження, погіршення 3 покоління в покоління певних рис або властивостей організму).

Стилістичне забарвлення складних слів пов'язане здебільшого 3 новим значенням, що виникає внаслідок поєднання слів або основ слів. Складні слова виконують різні стилістичні функції. Так, словоскладання, що становить редуплікацію (а часто повтор трьох однакових слів), виконує експресивну й емотивну функції. Крім того, повтор твірних має квалітативне значення, вносить відтінок частотності, поширеності, повторюваності, міри вияву ознаки: Колись-колись-колись Крим, як відомо, звався Таврія (3, с. 67); - Ти їздии-їздиш, стріляси-стріляєш, собак годуєш, а в Ганни Іванівни он яка чорнобурка! (3, с. 109); Серед очеретів тих густо-буйних озера-свічада, а на озерах латаття, а на озерах білі лілеї $і$ килимикилими-килими з темно-зеленої ряски... (3, с. 159); «Птиця» гречана на масть, з козинцями й худа-худа-худа... (3, с. 34); Як зацвітезацвіте-зацвіте (3, с. 46); Щоб не так прямо все йшло, а щзб отак- 
отак-отак (тут письменник не знайшов слів для пояснення своїх думок і оте показав пальцем) (3, с. 60).

Із других компонентів складних слів слід виокремити запозичені -лог(ія), -філь(ство), -фоб(ство), -ман(ія), які відзначаються виразним книжним забарвленням. Поєднання цих компонентів із стилістично або семантично невідповідними основами створює яскраві стилістичні ефекти. За зразком книжних складень, як свого роду «словотворчі пародії», утворює чимало похідних Остап Вишня: ...i ви знову маєте змогу не тільки, сказать би, поповнити свої продовольчі ресурси, не тільки допомогти державі в м'ясозаготівлях, а й задовольнити себе як природознавия, природофіла й спортсмена (3, с. 113); Коли роман складається з кількох книг, він уже тоді буде «логія". Як $з$ трьох книг - трилогія. 3 трьохсот книг трьохсотлогія. А як більше, то вже буде «Рятуйтелогія» (3, с. 59).

Своєрідність композитних утворень спостерігається передусім у лексичній семантиці, що грунтується на поєднанні значень компонентів: Жоднісінького тоді клаптика білотуманової на нім вовни! (3, с. 99); А в «яструбкові» сидить -може, білява, може, русява, може, чорнява - дівчинка й мертвопетлює, усміхаючись (3, с. 58). $\mathrm{У}$ наведених прикладах похідні утворені оказіональним способом: біло + тумановий, мертво + петлювати.

У мові творів Остапа Вишні чисельною є група складних слів, які поєднують несумісні поняття. За походженням твірні таких похідних можуть бути однієї мови і різномовними. Гуморист активно продукує слова, складні для вимови. Через їх надмірну величину (тричотири твірні основи) лексичні значення цих слів затемнюються i стають каламбурними: Зліталася туди вся «стомлена», «перетомлена», «виснажена», «недоїдаюча», «недопитюча» изарська аристократично-бюрократично-поміщицько-купецька Росія й відпочивала по гостиниях, по реставрачія, по яхтах, по автах, по фаетонах от «трудов праведних», громлячи дзеркала, лапаючи наяд пудронафарбованих і роблячи «акварї̈» з рояля та коробки сардинок за допомогою своєї триперо-діабетичної сечі... (3, с. 81); І розправлясться тоді й партійна, і радянська, і професійна людина, $i$ кудись іде, $i$ чогось хоче, $i$ співає, $i$ правою ногою радянськопартійно-професійною притакує, $і$ всміхається... (3, с. 97). Оказіональні похідні, утворені способом основоскладання, виконують ( Н. М. Малюга, 2016. 
компресивно-експресивну функцію. Іронія дає змогу приховати смуток автора, який усвідомлює трагізм реалій буття.

Схильність до конденсації семантики робить процес творення складних слів у поетичній мові досить продуктивним. Крім того, багато типів складних слів постають майже автоматично, за наявними в мові зразками, вони творяться в межах словотворчих і граматичних закономірностей загальнонародної мови.

Стилістичні функції субстантивації неоднакові в кожному конкретному випадку, але загалом вони залежать від двох причин: від ступеня субстантивації, яка може бути остаточною, частковою i каузальною (спорадичною), і від належності субстантивованих слів до певної лексико-семантичної групи. Якщо узуальні синкретичні слова переважно стилістично нейтральні, то оказіональні синкретичні слова експресивні: За двадцять чотири роки спільного їхнього життя послав їм Господь усього тільки сімнадиятеро дітей, бо вміли вони молитись милосердному (3, с. 4).

Особливо виразними є випадки оказіональної субстантивації звуконаслідувань (1) та вербалізації вигуків (2), що притаманне мовленню. Наприклад: (1) До Сімферополя Кримський півострів особливого собою нічого не уявляє, $і$ ви до того Сімферополя спокійно спите, лагідно похропуючи під тра-та-та пульманівського вагона (3, с. 63); (2) І ваша права сусідка - «ах!», і ваш лівий сусіда - «ах!», $i$ передні сусіди - «ах!», і задні сусіди - «ах!», і ви самі - «ах!»... Тільки сам шофер не «ах!», а косо на помічника: - Увага! (3, с. 66).

Задля створення комічного ефекту під час продукування власних назв та назв осіб за видом діяльності Остап Вишня вдається до лексикосинтаксичного способу словотвору, зокрема моделі «2 ос. одн. наказ. способу + Зн. в. одн.»: Кіндрат Калістратович Моргниоко, давній $i$ досвідчений убийвовк, - так він усім розповідав і всіх учив, щзо вовкзвір надто полохливий і боязкий (3, с. 126); Країна «Чукрен», як про те свідчать матеріали, знайдені при розкопках гробниці чухраӥнського иаря Передериматнюріохора, розлягалася на чималім просторіні від біблійської річки Сону до біблійської річки Дяну (3, с. 46). Твірною базою за такого способу творення виступає не будь-яке сполучення слів, а тільки синтаксична одиниця - словосполучення. Складне слово, утворене лексико-синтаксичним способом, переймає флексію другого слова словосполучення, тому флексія не визначається у словотвірній 
структурі мотивованого: моргни око $\rightarrow$ Моргниоко (+ онімізація); убий вовк $\rightarrow$ убийвовк.

Одним 3 основних способів продукування стилістично маркованих одиниць у мові Остапа Вишні є лексико-семантичний спосіб словотвору, при якому звукова форма твірного слова (мотиватора), залишаючись незмінною, набуває нового значення і стає семантично похідною (мотивованою).

Лексико-семантичний спосіб словотвору активно виявляється в системі номінації власних назв: А моя Мура так ніби не Мура, а ніби я, Кіндрат Стерня... (3, с. 50); Коли ось двері на ганок - рип! виходять троє: двоє, чую, фашисти, а третій Панько Нужник, - за старосту вони його призначили (3, с. 52). Прізвище Стерня, яким Остап Вишня наділив персонажа-селянина, власника корови, мотивується загальною назвою стерня 1. Поле, на якому зібрано хлібні рослини й залишилися лише зрізані біля кореня їхні стебла. 2. Зрізані біля кореня стебла хлібних рослин, що стоять на пні [2, с. 1194]. Прізвище Нужник мотивується відповідною загальною назвою, що означає те саме, що й убиральня 3. Приміщення, призначене для відправлення природних потреб людини [2, с. 1281]. Номінації не ізольовані від інших одиниць, як і від мовного контексту загалом, не замкнені в собі. Усі похідні взаємопов'язані й за формою, і за змістом, їхнє продукування і використання підпорядковане авторському задуму.

Наявність у мовній системі типових, регулярних і закономірних мотиваційних зв'язків уможливлює виділення таких різновидів лексико-семантичного способу, як-от:

- дериваційна метафора: В Харків «мене переїхали» 1920 року, в жовтні місячі (3, с. 9); Уже так, коли придивишся на волосся, видно, щзо щзодня «маститості» прибавляється. Швидко-ивидко вже замість волосся сама «маститість» на голові буде (3, с. 10);

- дериваційна метонімія: Читай Горація, Вергілія, Овідія та інших Гомерів (3, с. 7); $A$ «Зоя Владимировна» чи «Клара Соломоновна" зі своїми "Сєвкою" чи «Абрашкою» на веранді сидять, та ще й під парасолькою... (3, с. 19).

Метонімія $\epsilon$ більш важливим джерелом номінації як у кількісному плані, так і щодо різноманітності мотивацій для називання. Більшість лексико-семантичних інновацій Остапа Вишні твориться шляхом метонімізації, що пояснюється досить прозорими

๑ С. М. М. Малюга, 2016. 
мотиваційними зв'язками базового слова i новоутвореного найменування. Так, в останній ілюстрації лексико-семантичні деривати «Зоя Владимировна», «Клара Соломоновна», «Сєвка», «Абрашка» подають додаткову інформацію про національність та суспільний статус номінантів, відбувається перенесення за суміжністю.

Основними механізмами лексико-семантичного способу словотвору в цій підсистемі мови є онімізація (перехід загальної назви у власну); трансонімізація (перехід власної назви з одного класу назв до іншого); онімотрансонімізація (комбіноване використання різновидів способу за моделлю: онімізація + трансонімізація). Кожен 3 цих різновидів пов'язаний із семантичними і граматичними змінами мовних одиниць.

Як митець слова, Остап Вишня задля досягнення гумористичного ефекту досить часто вдається до свідомого застосування хибної мотивації: Або горобецьь на Основі на тину й горобець у Криму на пальмі! Різниця! На основі він горобець, а тут жсар-птиця, бо йому жарко! (3, с. 71); Султанка - це риба. Справжня риба. Зветься вона султанкою через те, щчо турецькі султани ніколи такої паршивої риби не їли (3, с. 74).

Остап Вишня свідомий того, що комічний ефект скорочує дистанцію в міжособистісному спілкуванні, сприяє розшифровці прихованої іронії, сприйняттю жартів. Підгрунтям комічного неодмінно є будь-які колізії, об'єднання в одне ціле кількох уявлень, чужих один одному за своїм внутрішнім змістом: Гори тут дуже лякливі! Назви в ӥх здебільше з «Ай» починаються: Ай-Петрі, Ай-Микола, Ай-Тодор, Aй-Я $і$ m. ін. (3, с. 77). Так, у перекладі з грецької «ай» - святий, відтак гора $A \check{\text {-П} П е т р і ~ о з н а ч а є ~ « г о р а ~ С в я т о г о ~ П е т р а », ~ А и ̆-Т о д о р ~-~ « г о р а ~ С в я т о г о ~}$ Федора» відповідно. Ай-Я - це мис «Святий», а вже Ай-Микола - жарт Остапа Вишні, оказіональне утворення за наявною моделлю.

У властивій іронічній манері гуморист, оперуючи біологічними термінами, описує коропів-гібридів: Не коропи, а жеребці! Вони в нас особливої породи - гібриди: мати дзеркальна, а батько - симентал (3, с. 180). Так, короп дзеркальний - порода коропа, що відрізняється тілом, нерівномірно вкритим лусками, із ділянками голої шкіри. Уважають, що дзеркальний короп був виведений селекцією ченцями, аби полегшити приготування для вживання в їжу. Рекордні за масою екземпляри коропа сягають маси до 25 кг (рекорд - 40,2 кг). 
Симентальська порода - порода великої рогатої худоби молочном'ясного напрямку. Виведена у Швейцарії. У Росію симентальську породу завозили 3 другої половини XIX століття. Биків використовували для схрещування 3 місцевою худобою. Завдяки схрещуванню з різними місцевими породами утворено кілька зональних типів Симентальської породи (сичевський, степовий, український, приволзький, приуральський, сибірський, далекосхідний). Бики важать 800-1100, корови - 550-600 кг. Тварини добре відгодовуються.

Остап Вишня успішно випробовує прийом тлумачення 1 ступеня - тлумачення 2 ступеня - тлумачення 3 ступеня тощо. Наприклад: Найстрашніший дикий кабан - «одинець», - це запеклий кнуріндивідуаліст, старий досвідчений кнуряка, щзо прибивається до табуна тільки тоді, коли свині весілля справляють (3, с. 152). Найстрашніший дикий кабан - «одинець» (1); «одинець» - це запеклий кнур-індивідуаліст (2); кнур-індивідуаліст (тобто «одинець») - старий досвідчений кнуряка (3). Пор.: Одинещь 2. мисл. Стара тварина, що веде самотній спосіб життя [2, с. 660]. Індивідуаліст. Людина, що виявляє індивідуалізм у поглядах, поведінці [2, с. 398].

Письменник, висміюючи невігластво і графоманію в науці, псевдоетимологічні тлумачення супроводжує псевдоісторичними коментарями: Звалася так та казкова країна через те, щзо ї̈ населення, люд тобто ї̈ божий, завжди чухався. <...>

Через те й країна звалася «Чукрен»...

Власне кажучи, перша ї̈ назва була не "Чукрен», а "Чухрен», але згодом «хи» перейшло в «ки», а правописна комісія той перехід «хи» на «ки» затвердила (3, с. 44).

Отже, письменник звертається до різноманітних і часто дуже оригінальних мовностилістичних засобів комічного. Свідоме використання хибної мотивації, псевдоетимологічних тлумачень $є$ визначальною ознакою стилю Остапа Вишні. Аналіз мовностилістичних засобів творення комічного $\epsilon$ важливим напрямком дослідження майстерності Остапа Вишні і повинно стати частиною грунтовнішого вивчення його творчої спадщини.

До словесних прийомів створення гумору, широко використовуваних Остапом Вишнею, слід віднести конструювання контрастних слів, не властивих літературній мові. Вони викликають сміх тим, що називають поняття незвично, дещо «вивернуто», так, як не 
прийнято говорити. Письменник шукає економну i змістовну форму створення образу, намагається знайти у слові нові відтінки значення, продукуючи індивідуальні комічні неологізми, в основу яких покладено принцип контрасту. Незважаючи на те, що такі одиниці переважно залишилися новоутвореннями індивідуального характеру, мовотворчість Остапа Вишні збагачує художній стиль мови і його виражальні засоби.

\section{Література}

1. Булаховський Л. А. Виникнення i розвиток літературних мов / Л. А. Булаховський // Мовознавство. - 1947. - Т. 4-5. - С. 116-173.

2. Великий тлумачний словник сучасної української мови : 170000 / [уклад., гол. ред. В. Т. Бусел]. - [3-є вид., доп.]. - К. - Ірпінь : Перун, 2003. - 1427 с.

3. Вишня О. Зенітка : Гуморески, усмішки / О. Вишня. - Дніпропетровськ : Січ, 1993. - $191 \mathrm{c}$.

4. Калита О. М. Мовні засоби вираження іронії в сучасній українській малій прозі : автореф. дис. ... канд. філол. наук / О. М. Калита. - К., 2006. -23 с.

5. Колоїз Ж. В. Українська оказіональна деривація : [монографія] / Ж. В. Колоїз. К. : Акцент, 2007. - $311 \mathrm{c.}$

6. Пришва Б. Г. Засоби гумору в творах Остапа Вишні / Б. Г. Пришва. - К. : Вища школа, 1977. - $118 \mathrm{c.}$

Стаття надійшла до редакиії 07.12.2015 p. 